\title{
Polyuria, Acidosis, and Coma Following Massive Ibuprofen Ingestion
}

\author{
Michael Levine • Amandeep Khurana • \\ Anne-Michelle Ruha
}

Published online: 24 April 2010

(C) American College of Medical Toxicology 2010

\begin{abstract}
Ibuprofen was the first over-the-counter nonsteroidal anti-inflammatory drug available in the United States. Despite being a common agent of ingestion, significant toxicity in overdose is rare. We report a case of a massive ibuprofen ingestion who developed polyuria, acidosis, and coma but survived, despite having a serum ibuprofen concentration greater than previous fatal cases. A 19 -year-old man ingested $90 \mathrm{~g}(1,200 \mathrm{mg} / \mathrm{kg})$ ibuprofen. He was initially awake and alert, but his level of consciousness deteriorated over several hours. Seven hours following the ingestion, he was intubated and mechanically ventilated secondary to loss of airway reflexes. He developed a lactic acidosis and polyuria, which lasted for nearly $24 \mathrm{~h}$. His serum creatinine peaked at $1.12 \mathrm{mg} / \mathrm{dL}$. An ibuprofen level drawn $7 \mathrm{~h}$ postingestion was $739.2 \mathrm{mg} / \mathrm{L}$ (therapeutic 5$49 \mathrm{mg} / \mathrm{L}$ ). We describe a case of a massive ibuprofen overdose characterized by metabolic acidosis, coma, and a state of high urine output who survived with aggressive supportive care. This case is unique in several ways. First, ibuprofen levels this high have only rarely been described. Second, polyuria is very poorly described following ibuprofen ingestions.
\end{abstract}

M. Levine - A.-M. Ruha

Department of Medical Toxicology,

Banner Good Samaritan Medical Center,

Phoenix, AZ, USA

M. Levine $(\square) \cdot$ A.-M. Ruha

Banner Good Samaritan Poison and Drug Information Center, Phoenix, AZ, USA

e-mail: Michael.Levine@bannerhealth.com

A. Khurana

Southwest Kidney Institute,

Phoenix, AZ, USA
Keywords Ibuprofen · Coma - Metabolic acidosis . Polyuria $\cdot$ Acute tubular necrosis $\cdot$ NSAID $\cdot$ Toxicity

\section{Introduction}

Ibuprofen is a nonnarcotic analgesic and anti-inflammatory agent which has been available in the United States without a prescription since 1984 . In 2007 , there were more than 79,000 cases of ibuprofen ingestion reported to poison centers in the United States [1]. While the vast majority of ingestions result in little morbidity, ingestions exceeding $400 \mathrm{mg} / \mathrm{kg}$ can produce coma, acidosis, and rarely death.

\section{Case Report}

A 19-year-old male with no significant past medical history presented to an emergency department following an ibuprofen ingestion. The patient reportedly got into an argument with his girlfriend, prompting him to drink one $1,180 \mathrm{~mL}$ beer, and $3 \mathrm{~h}$ later, to ingest 450 tablets of $200 \mathrm{mg}$ ibuprofen $(90,000 \mathrm{mg}$ total; $1,200 \mathrm{mg} / \mathrm{kg})$. The ibuprofen ingestion occurred approximately $90 \mathrm{~min}$ prior to arrival in the emergency department. He called EMS himself after feeling "remorseful." Upon arrival, the patient's blood pressure was $126 / 74 \mathrm{mmHg}$, with a heart rate of $85 \mathrm{bpm}$. His initial exam was only notable for some diffuse muscle "twitching." The patient was intravenously given $2 \mathrm{~L}$ of crystalloid over the first $3 \mathrm{~h}$ in the Emergency Department and was placed on a lactated ringers infusion at $250 \mathrm{~cm}^{3} / \mathrm{h}$. His laboratory studies, including a complete blood count, electrolytes, renal and liver function tests, and lactic acid, as well as quantitative levels of ethanol, salicylate, lithium, and acetaminophen, were only notable 
for a potassium of $3.2 \mathrm{mmol} / \mathrm{L}$, a lactic acid of $3.6 \mathrm{mmol} / \mathrm{L}$, and an ethanol level of $38 \mathrm{mg} / \mathrm{dL}$. His hemoglobin was $14.1 \mathrm{~g} / \mathrm{dL}$, creatinine was $0.89 \mathrm{mg} / \mathrm{dL}$, and glucose was $100 \mathrm{mg} / \mathrm{dL}$. Three hours after the ingestion the patient developed a mild tachycardia and became more agitated. His 12-lead electrocardiogram demonstrated sinus tachycardia at $106 \mathrm{bpm}$ with a normal axis. The PR, QRS, and QTc intervals were 164, 96, and $473 \mathrm{~ms}$, respectively. A CT scan of his head was negative. He was ultimately transferred to our institution.

During transport, the patient's level of consciousness continued to decline. Upon arrival at our institution, approximately $7 \mathrm{~h}$ postingestion, his blood pressure was 133/ $49 \mathrm{mmHg}$ with a heart rate of $130 \mathrm{bpm}$. He was hypothermic with a core temperature of $35.8^{\circ} \mathrm{C}$, and his oxygen saturation on $2 \mathrm{~L} \mathrm{O}_{2}$ via nasal cannula was $98 \%$. His skin was warm and well perfused with moist mucosal membranes. Abdomen was soft and nondistended with bowel sounds present. Rectal exam revealed guaiac positive stools, but no melena. He had occasional muscular twitches and fasciculations in all major muscle groups and would withdraw to painful stimuli. His face was symmetric without droop, and his pupils were symmetric at $4 \mathrm{~mm}$. No posturing was noted. Because he had no gag reflex, he was intubated upon arrival at our institution. An orogastric tube was placed which revealed bloody aspirate. A venous blood gas, performed immediately before intubation, revealed a metabolic acidosis with a $\mathrm{pH}$ of 7.21. His anion gap was 15 . Other laboratory studies obtained at that time included a lactic acid of $5.9 \mathrm{mmol} / \mathrm{L}$, sodium $145 \mathrm{mmol} / \mathrm{L}$, potassium $4.4 \mathrm{mmol} / \mathrm{L}$, chloride $111 \mathrm{mmol} / \mathrm{L}$, bicarbonate $19 \mathrm{mmol} / \mathrm{L}$, BUN $8 \mathrm{mg} / \mathrm{dL}$, creatinine $0.98 \mathrm{mg} / \mathrm{dL}$, and a glucose of $98 \mathrm{mg} / \mathrm{dL}$. An abdominal radiograph revealed no radiopaque foreign bodies, and a chest radiograph revealed the presence of an orogastric tube and an endotracheal tube, with no acute cardiopulmonary process. A serum ibuprofen concentration obtained $7.5 \mathrm{~h}$ postingestion was $739.2 \mathrm{mg} / \mathrm{L}$ (therapeutic 5-49 mg/L). Gas chromatography/mass spectrometry testing of urine detected only ibuprofen, caffeine, nicotine, and cotinine.

He was empirically placed on propofol and fentanyl drips, as he did have some spontaneous movements, although no purposeful movements. In the hour after intubating him and starting propofol and fentanyl, the mean arterial pressure decreased approximately $20 \mathrm{mmHg}$, and the heart rate decreased approximately $25 \mathrm{bpm}$. He remained hypothermic for nearly $24 \mathrm{~h}$ postingestion. An arterial blood gas obtained $12 \mathrm{~h}$ postingestion revealed a $\mathrm{pH}$ of 7.27 with a $\mathrm{PCO}_{2}$ of 43.8 and base deficit of 6.8. Thirteen hours after the ingestion, the anion gap had closed, but the lactic acid was still elevated at $3.3 \mathrm{mmol} / \mathrm{L}$. The lactic acid normalized $(1.1 \mathrm{mmol} / \mathrm{L})$ approximately $24 \mathrm{~h}$ postingestion. The patient's creatinine rose slightly, peaking at $1.2 \mathrm{mg} / \mathrm{dL} 30 \mathrm{~h}$ postingestion, despite aggressive fluid resuscitation. His urine sodium was
$157 \mathrm{mmol} / \mathrm{L}$, and the urine creatinine was $26 \mathrm{mg} / \mathrm{dL}$, with a fractional excretion of sodium more than $1 \%$, consistent with acute tubular necrosis (ATN).

Despite receiving only $2.5 \mathrm{~L}$ of fluid in the first $7 \mathrm{~h}$ after the ingestion, the patient voided nearly $1,800 \mathrm{~cm}^{3} / \mathrm{h}$ for the first $2 \mathrm{~h}$ after arrival at our center. He was given an additional $2 \mathrm{~L}$ of lactated ringers over $2 \mathrm{~h}$ and continued on a maintenance IVF rate of $200 \mathrm{~mL} / \mathrm{h}$. He continued to void more than $400 \mathrm{~cm}^{3} / \mathrm{h}$ for the subsequent $12 \mathrm{~h}$. Further boluses were administered as needed to keep up with his urine output. Approximately $21 \mathrm{~h}$ postingestion, the patient became oliguric for $3 \mathrm{~h}$, at which time he received an additional liter of lactated ringers, resulting in a substantial increase in his urine output. In total, during the first 2 days, the patient received $11.23 \mathrm{~L}$ of IVF with an output of $15.18 \mathrm{~L}$ of urine. The large volume of IVF was in response to his excessive output. Postextubation, the patient was drinking $240-320 \mathrm{~cm}^{3} / \mathrm{h}$ of fluid.

The urinalysis revealed 31-60 red blood cells per high power field, and 1-5 white blood cells per high power field. No protein, ketones, or bacteria were observed in the urine. He never had any significant serum sodium abnormalities (sodium fluctuated from 139 to $146 \mathrm{mmol} / \mathrm{L}$ ).

The patient's mental status also began improving approximately $18 \mathrm{~h}$ postingestion, and he was able to be extubated $25 \mathrm{~h}$ postingestion. The patient did confirm the history of ingesting approximately 450 tablets of ibuprofen. He was seen by the psychiatry service, and was ultimately transferred to in-patient psychiatric care.

\section{Discussion}

In 1984, ibuprofen (2-4-isobutylphhenyl propionic acid) became the first nonsteroidal anti-inflammatory agent to be approved for use without a prescription. Because of its availability and low cost, overdose with this agent remains common. Following ingestion, most patients remain asymptomatic or develop only mild gastrointestinal upset, including nausea, vomiting, and epigastric pain. Neurologic symptoms, such as lethargy, headache, and nystagmus can occur as well $[2,3]$. Acute renal injury has uncommonly been described [4]. While mefenamic acid has classically been associated with seizures, both muscle twitches and seizures have been reported with acute ibuprofen overdose as well $[3,5]$. As a general rule, ibuprofen ingestions exceeding $400 \mathrm{mg} / \mathrm{kg}$ are potentially toxic. Nonetheless, life-threatening reactions, such as coma, acidosis, or renal failure remain rare.

Previous investigators have also described massive ingestions, with variable outcomes. In the late 1980s, Linden and colleagues reported two pediatric patients who developed CNS and respiratory depression, along with a metabolic acidosis. A serum ibuprofen level of $680 \mathrm{mg} / \mathrm{L}$ 
was obtained in one of these children. Both children survived [3]. Lee and Finkler reported an ingestion of $>20 \mathrm{~g}$ of ibuprofen which resulted in multisystem organ failure, but the patient ultimately survived. The serum level in this case was $185 \mathrm{mg} / \mathrm{L}$ [6]. Oker and colleagues described an 18-month-old who ingested $600 \mathrm{mg} / \mathrm{kg}$ of ibuprofen. $\mathrm{He}$ developed a tonic-clonic seizure, respiratory failure, and metabolic acidosis. In their case, a 4-h ibuprofen level was $640 \mathrm{mg} / \mathrm{L}$. The child survived without long-term sequelae [7]. Lastly, Holubek and colleagues described two fatal ibuprofen ingestions. One patient, a 17-year-old woman who was found unresponsive, had a capillary glucose of $2 \mathrm{mg} / \mathrm{dL}$ and a lactic acid of $17 \mathrm{mmol} / \mathrm{L}$. She had diffuse cerebral edema on neuroimaging. Her toxicology studies revealed the presence of cocaine in her urine and a serum ibuprofen concentration of $352 \mathrm{mcg} / \mathrm{L}$. Their second case was a 49year-old man who presented unresponsive and hypotensive with metabolic acidosis. The patient's ammonia was 639 $\mathrm{mcg} / \mathrm{dL}$. Toxicology testing revealed a valproic acid concentration of $560 \mathrm{mg} / \mathrm{L}$ and an ibuprofen concentration of $260 \mathrm{mg} / \mathrm{L}$ [8]. Wood and colleagues describe a fatal ingestion of ibuprofen in a 26-year-old female who ingested up to $105 \mathrm{~g}$ of sustained-release ibuprofen. She developed central nervous system depression, metabolic acidosis, and ultimately, died. Her ante-mortem ibuprofen level from peripheral blood was $760 \mathrm{mg} / \mathrm{L}$ [9].

Marciniak and colleagues have described a 75-kg 14year-old who was found unresponsive next to an empty bottle of 500 tablets of ibuprofen (200 mg each). This patient was hypotensive, tachycardic, and acidotic. His toxicology studies revealed an ibuprofen concentration of $776 \mathrm{mg} / \mathrm{L}$. This patient also had a high output state with $29 \mathrm{~L}$ of urine produced during the first $16 \mathrm{~h}$ of admission. However, this patient developed renal failure. The patient ultimately was placed on full venoarterial extracorporeal membrane oxygenation before making a full recovery [10].

Our patient's renal abnormalities have not been previously described. In the absence of significant comorbidities or hypovolemia, angiotensin concentrations are typically low. In patients with hypovolemia or intrinsic renal disease, however, there is a high angiotensin state with GFR maintained by prostaglandin-mediated afferent arteriolar vasodilatation and angiotensin II-dependent efferent arteriolar vasoconstriction. The NSAID-induced reduction in prostaglandins can result in vasoconstriction of the afferent arterioles and, hence, reduced GFR [11]. Prolonged reduction in afferent blood flow can lead to ischemic ATN, which is probably what happened to our patient.

Other renal conditions associated with NSAID use include tubulointerstitial nephritis, minimal change disease, membranous nephropathy, papillary necrosis, hyperkalemia, and exacerbation of hypertension [12]. Our patient never had proteinuria, although his creatinine did increase mildly.

The acidosis has been previously described. While its exact mechanism of action is not known, it is likely from accumulation of propionic acid [3]. Despite occasionally finding significantly elevated levels in symptomatic patients, the routine use of ibuprofen levels is not warranted, as it does not change management [13].

This case has several unique aspects. First, our patient developed polyuria, which is generally defined as a urine output of more than $3 \mathrm{~L}$ urine per $24 \mathrm{~h}$. Polyuria following ibuprofen ingestions has not previously been described in the absence of more significant acute renal failure. Secondly, the serum ibuprofen concentrations are rarely elevated to this degree. Our case demonstrates that with prompt and aggressive supportive care, even patients with truly massive ibuprofen ingestions can make full recovery.

Conflict of Interest There are no financial, litigable, or other conflicts of interest to disclose.

\section{References}

1. Bronstein AC, Spyker DA, Cantilena LR et al (2008) 2007 Annual report of the American Association of Poison Control Centers' National Poisoning Data System (NPDS): 25th Annual Report. Clin Tox 46:927-1057

2. Volans G, Monaghan J, Colbridge M (2003) Ibuprofen overdose. Int J Clin Pract Suppl 135:54-60

3. Linden CH, Townsend PL (1987) Metabolic acidosis after acute ibuprofen overdosage. J Pediatr 111:922-925

4. Hall AH, Smolinske SC, Conrad FL et al (1986) Ibuprofen overdose: 126 cases. Ann Emerg Med 15:1308-1313

5. Smolinske SC, Hall AH, Vandenberg SA et al (1990) Toxic effects of nonsteroidal anti-inflammatory drugs in overdose. An overview of recent evidence on clinical effects and dose-response relationships. Drug Saf 5:252-274

6. Lee CY, Finkler A (1986) Acute intoxication due to ibuprofen overdose. Arch Pathol Lab Med 110:747-749

7. Oker EE, Hermann L, Baum CR et al (2000) Serious toxicity in a young child due to ibuprofen. Acad Emerg Med 7:821-823

8. Holubek W, Stolbach A, Nurok S et al (2007) A report of two deaths from massive ibuprofen ingestion. J Med Toxicol 3:52-55

9. Wood DM, Monaghan J, Streete P et al (2006) Fatality after deliberate ingestion of sustained-release ibuprofen: case report. Crit Care 10:R44

10. Marciniak KE, Thomas IH, Brogan TV et al (2007) Massive ibuprofen overdose requiring extracorporeal membrane oxygenation for cardiovascular support. Pediatr Crit Care Med 8:180-182

11. Harris RC (2006) COX-2 and the kidney. J Cardiovasc Pharmacol 47:S37-42

12. Henrich WL (1998) Analgesic nephropathy. Trans Am Clin Climatol Assoc 109:147-158

13. McElwee NE, Veltri JC, Bradford DC et al (1990) A prospective, population-based study of acute ibuprofen overdose: complications are rare and routine serum levels not warranted. Ann Emerg Med 19:657-662 